\title{
Analyzing Level Of Sexual Harassment And Exploitation Of Female Domestic Workers
}

\author{
Seema Manzoor \\ \& \\ Dua-e-Rehma \\ Women's Studies \\ University of Karachi \\ Misbah B. Qureshi \\ Institute of Gender Studies \\ Sindh University Jamshoro, \\ Muhammad Shahid \\ Department of Social Work \\ University of Karachi
}

\begin{abstract}
This study aims to establish the understanding and producing realistic information about the level of sexual harassment and exploitation of female domestic workers. The study has also tried to analyze the issues which affect the life of women working as domestic workers and facing great challenges. In Pakistan number of female domestic workers is growing dut to poverty, lack of education and inflation. By using quantitative research method researcher has analyzed different factors and circumstances which these women are experiencing, different areas of Karachi are chosen as universe of population for this study. Whereas, convenience and purposive sampling techniques of non-probability sampling method are used in order to collect the data by hundred respondents from different areas of Karachi. In Pakistan now more women are connected to labour force due to increased employment opportunities, on the other hand women are doing work outside their homes to gain their economic independence and the rights and social standing like men in the family and society. But they face exploitation, sexual harassment and discrimination.
\end{abstract}

Keywords: Female Domestic Workers, Harassment, Exploitation, Level of Awareness.

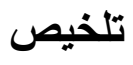

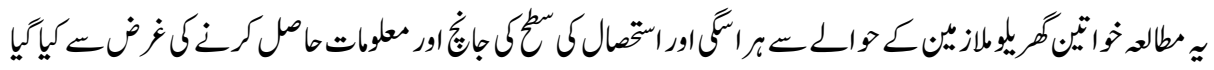

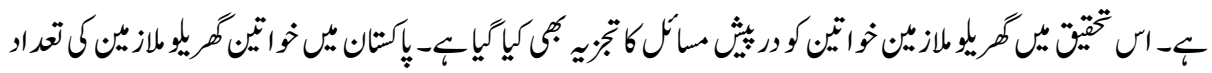

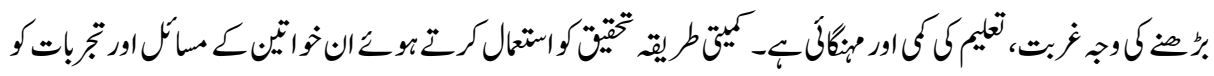




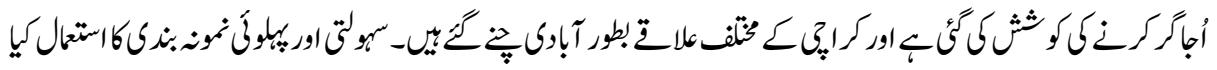

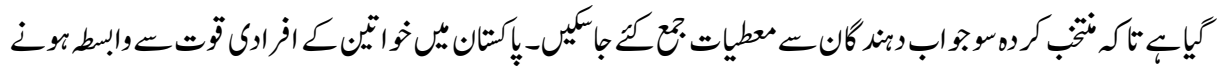

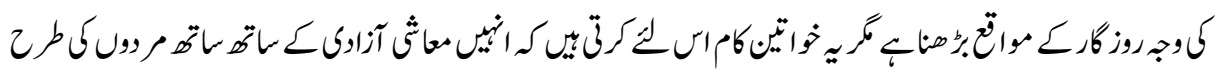

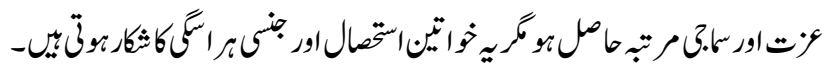

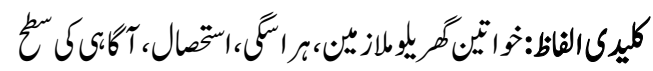

\section{Introduction}

A person who manages the household chores of the employer is generally called domestic worker or a helper. Domestic workers do various household jobs either for any individual member or for an entire family. They have to take care of children and elderly people, because they are partially of completely dependent on them, besides this their main responsibilities are cooking, cleaning, laundry, ironing and grocery. Some domestic workers work and leave, whereas, few stay at the employer's place. Sometimes their skills and efficiency is appreciated and valued, but in most of the cases it does not happen. In many countries laws and policies are formulated to protect their rights, but these laws are not implicated forcefully. In many countries the laws regarding domestic workers are violated and these poor people face many problems like low wages, extra work load, sexual abuse, harassment and even slavery (Anti Slavery International, n.d). Domestic work is not easy to categorize because it involves a variety of activities both indoor and outdoor. Workers who are employed through agencies get benefits from contracts and agreements. But mostly they are employed on individual capacity by the employer. From the days of slavery till today domestic workers have been experiencing various problems based on their backgrounds and class to which they belong. The irony is that usually women and young girls are hired as domestic workers, but their skills and work is unrecognized because it is considered that women are born to do domestic chores either as owner of the house or as a servant. Since their work is not considered as work, therefore, a collection of data about domestic workers is difficult throughout the world. Key reasons of inaccurate and adequate data are huge number of unregistered employees as domestic workers. One of the reasons of under-representation of these workers is considering them as people serving a community and delivering their services on a personal or social level. Therefore, they remain dependent on their employer and their dignity is not recognized as a human being. Employees whose work place is also their residence are fully controlled by the employer, their future and decisions are in their hands. And do not have the job security benefits like pension in old age. All such circumstances make them suffer more and more. 
Women and young girls are considered a soft target to harass and are even sexually abused. Scolding is very common and sometimes they are punished by being beaten. Women workers have relatively higher chances of sexual abuse and harassment by male members of the employer family or by the visitors. Studies show that girl domestic workers are victimized sexually and they are even raped. Girl domestic workers face harsh and rough attitude of the owner and other family members and are considered inferior. Sometimes they are not even aware how to protect themselves, which adds to the complexity of the problem (Massey, 1997). Along with sexual abuse another problem they face is low wages, which they cannot claim at any forum to get their rights. All over the world domestic workers are less paid and they hardly get any recognition (Shahid, 2007). Domestic work is considered an easy way to generate income for women. Keeping a house maid is a common trend in developed and developing countries to perform household chores. In Pakistan a larger number of women (local and migrant) are employed as domestic worker. It is an informal form of work, unorganized and nonregulated. In Pakistan, women work as house maids due to poverty and lack of education. They try to share the economic burden of the family's male members.

There is no fix pay scale for part-time and full-time domestic workers, but it varies as per location, type of work and economic status of the employer. Full-time domestic workers earn between four to five thousand rupees, live-in-workers earn between nine to twelve thousand rupees, whereas, workers who work for two to three hours and they carry out single job, earn between two to three thousand rupees. Carrying out single job for two to three hours is called "Khula Kaam", "Chutta Kaam" or "part-time work". In Pakistan, house maids are employed on word of mouth through relatives, neighbours or friends, no contract system or documentation is done before hiring them. Very few people contact employment agencies because usually people think it is a waste of money to pay to that agency also for providing them domestic employee. In such case employee's record is not maintained through which they can be monitored or can be tracked. Getting employee from agencies is safe because they maintain records of these domestic workers by keeping their CNIC, finger prints, address and other details attested by the area councilor and then this record is given to the area police station to track them in any type of suspicious activity from them. Since there is no specific law regarding the pay scale and working hours of domestic workers, therefore, wages and working schedule is according to the financial status and need of the employer. This working criterion becomes the reason of exploitation of domestic workers. Domestic work has different definitions regarding workplace for employee and the employer, i.e. one's workplace is the home or property of another and for the employee someone's private space becomes the public space that is their workplace. Some employer claims that their employee is part of their family, but on the other hand, they exploit them and even they become the victim of sexual abuse, they are degraded and humiliated and their dignity as human is not maintained. Because it is a power relationship, where one is stronger and the other is sub- 
ordinate, even their basic rights are not given to them like the right to rest, right to privacy and right to take off from work timely. This power relationship has widened the class differences in our society. Employing a domestic worker highlights status of the employer and keeping more than one employee has become the status symbol in Pakistan. These workers are not called by their real names rather they are called as "Maasi, Ayah Amma, Bua, Jamadarni" and the employer by the names which shows their higher status like "Begum Sahab, Shab Ji, Baray Sahab, Kahn Ji". The term domestic worker is specifically used for employees who work in someone's private space. Women work as a domestic worker in a huge ratio, but remain unrecognized. These women are either local or they migrate to big cities in search of a better life and employment "Rozgar" (Little, 1842:934).

Employing women as domestic worker demonstrates the clear gender inequality in our society, because women as hired on low wages for domestic chores like cleaning, washing dishes and clothes. Whereas, men are employed as drivers, cooks, etc. and they get comparatively better salary than women. In order to improve this situation it is needed to have clear policies regarding domestic work, especially to protect women from any kind of exploitation and abuse. Secondly, domestic work should be considered as a separate sector in the service industry, and thirdly domestic work should be considered as work so that it can get full coverage under labour laws. These steps will definitely improve the social and economic status, as well as will improve their inferior state from housekeepers to productive labour. According to the Constitution of Islamic Republic of Pakistan, Article 17 states that "every citizen has the right to form associations or unions, subject to reasonable restrictions imposed by law in the interest of sovereignty or integrity of Pakistan, public order or morality". But there are no specific unions or organizations to support women domestic workers. If these unions and organizations

provide their full support to domestic workers than their issues can be resolved to a certain extent (Shahid, 2014). Media and other social mediums can also raise awareness and can play a productive role in enhancing the dignified status of domestic workers in the society (Government of Pakistan, 2005). Above all, the most important thing is to provide them adequate health facilities, basic facilities and education. Along with this "Zakat System" should be made effective by keeping a welfare approach in mind, thus making Pakistan a welfare state on the basis of Islamic principles for the welfare of needy and poor people (David, 1992).

\section{Theoretical Framework}

Feminist theories try to give a theoretical perspective of women's socio-economic and political status (Barrington, 2009). Feminism has basically focused on gender issues while stressing on women's issues, their experience and traditional knowledge (Boonzaier \& Shefer, 2006). Though gender is the main structure of feminism, but along 
with that feminism also focuses on analyzing other social inequalities like race, class, caste and patriarchy. Feminism does not agree with the concept that human functioning based theories can be derived from researches conducted by men only. In fact it recognizes the fact that people may have different approaches, identities and communication skills, and women can have different experience on the basis of environment, culture in which they live with various social issues. Feminism floats the idea that identities and experiences of women are the creation of a wide range of social barriers and restrictions which they face in their life (DeVoe, 1990).

\section{Review Literature}

The basic aim of review literature is to give readers an analysis on a specific topic through the prism of quality research material which is appropriate, relevant, valid and important by compiling them into one complete report. It also creates a space for other researchers to research on the same topic by exploring its new dimensions. With time people's perspective has changed worldwide, things and concepts which were not of much importance before have now become the commodity and a social necessity. Social changes are occurring world over and with time the need and demand of domestic workers and their services have increased considerably. Among all social classes this trend is increasing more in the middle class (Cohen, 1991; de Regt, 2009). Thus more women are seen engaged in domestic work. According to studies in 2004, in South Africa domestic employment sector was the second largest employment sector and around 755,000 women were engaged in domestic work (StatsSA, 2005). It is obvious that usually women who lack in formal education acquire employment as domestic workers (Mkandawire-Valhmu et al., 2009). These changing trends in informal employment South Africa took measures to formalize the domestic sector employment. Many laws regarding minimum wage and protection of employees, under labour laws were the major step. However, these laws made not much of a difference as still many women suffer from exploitation and hazardous working conditions, and worst is that they face sexual assault from their employer (Cock, 1981).

Lower class women find domestic work quite tempting, because in this employment sector sometimes they get income and protection also. If the employees are migrants then the employer might provide shelter also which is their prime requirement (MkandawireValhmu et al., 2009). Even unskilled or women having low level of skills get job easily because domestic work is considered an inborn skill of women. (Gaitskel et al., 1983). Therefore, household chores can be referred to as a usual form of work for the employer. Many researches are conducted on domestic workers, mainly focusing on the nature of domestic work, the level of harassment and exploitation, social inequalities between the employee and the employer (Cohen, 1991; Cock, 2011; Mkandawire-Valhmu, 2010). Domestic workers are also considered the subject of research by the social scientists 
(Griffini, 2011; Guo, Chow \& Palinkas, 2011; Lycklama, 1989; Ukwata, 2010). But the subject of the problems which domestic workers face is not much explored (Acher, 2011). Female domestic workers due to their inferior social status, face gender discrimination, class and racial oppression and sometimes they even face violence from their employer. And this violence is due to power hierarchy (Cock, 1980; Cohen, 2000). The violence and abuse are usually in the form of extra work load, food deprivation and even hitting. These women suffer worst attitude and behaviour of the employer in the form of verbal abuse, humiliation and physical abuse. Their low status, economic dependency of employer and racial inequality creates room for violence and abuse of all forms.

The hardships which domestic workers, especially young girls and women face are because of weak support system for being away from home. They are mostly unaware about their rights thus, become easy victims of abuse and exploitation. Working away from home, health issues due to inadequate access to health resources and hazardous working conditions add to their miseries. Studies have identified that domestic work is not categorized as proper job and these workers face critical issues due to lack of recognition of their work. They are considered as helpers rather than workers, which makes them more vulnerable to abuse and exploitation. If they live with the employer then they have to bear their behaviour even if it is worst in the shape of heavy labour and abusive working conditions. People engaged in domestic employment sector are either called domestic worker or helper but still there is no proper definition of this concept. Ignoring this sector is actually causing problems and adding to the troubles of domestic workers. In 1951 ILO gave a general idea about the domestic work in a meeting, but failed to cover all the problem areas of this employment sector which is definitely an informal sector. At that time domestic employees were considered wage earners, but still nothing has changed much. Domestic workers are not considered as a contributor in the informal sector, in fact, they are just income generators. These workers work in a private household and their mode of work and salary depends on the employers will. Sometimes their salary is even deducted if they get sick and cannot perform their work as per schedule (ILO, 1951). The range of nature of work performed by these workers is very wide. The nature of domestic work is not well defined; everything within the home premises is included in domestic chores and is considered low skilled tasks. In domestic work employee has no capacity to do things by their method or skills tend to emotional and psychological turmoil, thus creating an unbalanced and unequal power relationship between worker and employer. It is usually considered as a work which women perform therefore, it is commonly perceived as women's job (M. Gallotti, 2009).

Research findings estimate that in Pakistan around " 8.5 million" domestic workers are women and young females. Women being weak and having a low social status become easy victims of all sorts of discrimination and exploitation which includes: fear of losing job, long working hours, extraordinary workload, lack of rest, no holidays, less salary, 
sexual abuse and even the accusations of robbery. Employers do provide some facilities occasionally and offer clothes, food, other items and financial and medical assistance from Zakat. But these occasional acts of charity are no alternate to human dignity and their rights which they should be entitled legally. Such charity acts humiliate them more by lowering their dignity. Currently worldwide, there is no specific law regarding domestic labour (Hisham, 2015).

Pakistan is a developing nation and has a huge poor population, who are unable to access the resources needed to lead their life in a proper manner by all means. Therefore, they seek any possible opportunity that guarantees income. More than 8.5 million domestic workers in Pakistan are engaged in this employment sector. Such poor living conditions promote domestic employment which has no future security. Under age children and even senior citizens are forced to do work to generate income for themselves and their family. Elite class heir domestic servants to carry out their domestic chores and also to maintain their status symbol. Mostly the entire family men, women and children are involved in income generation by doing odd jobs, but it is not enough for their survival due to inflation. In Pakistan people migrate from rural areas to big cities to earn money. The nature of job and payment is decided by the hirer, which is definitely not according to the work. Some employer provides the travel expenses or pick and drop, but this happens rarely (Shehzadi, 2014).

The constitution of Pakistan assures the rights of education for women, children and minorities. It also ensures the social, economic and political independence and providing decent living by providing decent employment and security. Article 3 and Article 11 prohibits all kinds of discrimination and forced labour. Similarly, some other Article e.g. Article 17, Article 25, Article 27, Article 37 and Article 38 also guarantee justice, equality, social well-being and abolition of equitable adjustment of rights between employers and employees (Iqbal, 2015). If these laws are implicated as it is then only labour can get the benefit, else they will keep facing discrimination.

\section{Methodology}

This study analyzes the level of harassment and exploitation of female domestic workers. Therefore, the study focused on collecting data regarding their harassment issues by using quantitative research method and descriptive survey method from women working as domestic works. Convenience and purposive sampling techniques of non-probability sampling method are used in order to collect the data by hundred respondents from various areas of Karachi, Sindh like Gulistan-e-Johar, Gulshan-e-Iqbal, Malir \& Bahadurabad etc. Descriptive method is used to get the insight and exact situation about the harassment and exploitation issues of women working as domestic workers, to highlight the affects of work on their lives and its impact on their physical and mental health. 


\section{Results and Discussion}

This study analyzes the level of harassment and exploitation faced by female domestic workers while working in different house. Despite their important role, these female workers are very vulnerable to sexual harassment and are supposed to become easy targets. It also examines the level of harassment these workers are facing. The report is based on the interviews conducted with a total number of 100 female domestic workers engaged in doing multiple duties such as cleaning, washing, cooking, caring for children or the elderly etc. All these domestic workers interviewed alleged their owners had also verbally abused them by shouting at them and using abusive language. According to the findings of the study data shows that $28 \%$ of respondents belong to the age group of more than 30 years, $22 \%$ belongs to $16-20$ years, $21 \%$ belongs to the age group of $21-25$ years whereas $15 \%$ of the respondents belong to the age bracket of 26-30 years and $14 \%$ belongs to the age group of 11-15 years. These figures identifies that females of all ages are involved in domestic work because of their weak economic status and lack of education which is clearly reflected from the data that when asking about the educational status of the respondents $64 \%$ of the respondents said that they were illiterate while $36 \%$ were literate. This figure clearly indicates that majority of the domestic workers were illiterate and those who are literate were also not highly qualified (Table-1 \& Table-2). It also shows that 33\% of the respondents were unmarried, $29 \%$ were married, whereas $14 \%$ were divorced while $12 \%$ each were widowed and temporarily separated. All of them were poor and worked as domestic worker to support their families. The income of the respondent as reflected from the data that $36 \%$ falls in the category of $1000-3000,20 \%$ in the category of $3100-5000$, $18 \%$ were earning between 5001-7000, while $16 \%$ falls in the category of $7100-9000$, and $10 \%$ were those who were earning more than 9000 per month to meet their daily needs. Remuneration paid to these female domestic workers are usually low as compared to male workers both in absolute terms as well as compared to other occupations (Table-3 \& Table-4). Data has shown that $48 \%$ of the respondents said that they started work just to improve the financial status of their family, $29 \%$ said that they started work because their other family members do not earn and $23 \%$ said that they started doing work for their children (Table-5).

Data has clearly reflects the behaviour of the employer with their female domestic workers that $32 \%$ of the respondents said that their owner were moody, $29 \%$ said that their behaviour towards them was good, $20 \%$ said that they were carrying and $19 \%$ said that their behaviour was bad and they mistreated them (Table-6). While asking about the awareness about sexual harassment $66 \%$ of the respondents replied that they were aware and 34\% said that they do not know about sexual harassment (Table-7) whereas 54\% of the respondents said that they were several times sexually harassed by their owner while $46 \%$ 
of the respondents were never been sexually harassed by their owners (Table-8). In this connection when enquired about the extent of the sexual harassment occurred $36 \%$ of the respondents said that they had never been harassed, 33\% reported touching and holdings hands, $16 \%$ said that their owners were making love to them and $15 \%$ said that they faced extreme level of sexual harassment (Table-9). Female domestic workers face potentially many problems during their job they were extremely insecure, were face sexual harassment, physically and verbally abused by their employer or other family members of the employer which is clearly reflected in this study. Data has also shown that $26 \%$ of the respondents said that they got angry when they were sexually abused, $22 \%$ show their rude attitude and $16 \%$ said abusive words to the perpetrator (Table-10). When asking about that did they inform any one about the incident of sexual harassment $40 \%$ said that they were never been harassed, 31\% said that they inform someone about the incident awhile $29 \%$ said that they did not inform anyone because they have the fear that no one can believe them nor help them (Table-11). As per data $36 \%$ of the respondents keep silence after the incident and $24 \%$ of the respondents were those who warned their female relatives about sexual harassment after being victimised. It also reflects that $50 \%$ of the respondents said that other female domestic workers also share the incidents of sexual harassment they faced (Table-12 \& Table-13) and 37\% of the respondents said that they also gave advice to their colleagues to be careful and vigilant while working that no one can take any undue advantage and harass them (Table-14) whereas 30\% respondents said that they were very much disturbed and face mental stress and depression due to sexual harassment (Table15). Female domestic workers are subject to various kinds of abuses; being beaten and being shouted is a common punishment for working slow or doing any mistakes. These female workers are at high risk of sexual harassment not only by the male members of the employer's household but also by their male visitors. Some victims choose to remain quiet and not to report the incident to anyone as they safeguard their future by doing this because they have a fear of losing their jobs though this fear is not entirely reasonable. Some times when they share their incident to their relatives they persuaded them to stay quiet by telling them that the incident would put their future in danger and they might not be hired again because of their bad repo due to this incident.

When asking about that do they know about the sexual harassment bill $46 \%$ of the respondents said that they do not know about the existence of any such bill (Table-16). While giving their opinion about sexual harassment $31 \%$ said that men always exploit women, $26 \%$ said that women are physically weak and become harassment victim easily, whereas $24 \%$ said that women should be strong enough so that men cannot harass them and $19 \%$ of the respondents said that men manipulate women and exploit them (Table-17). 


\section{Conclusions}

The study has been carried out to identify and evaluate the issues faced by the working women in domestic employment sector. The study reveals that in the presence of legal cover and labour laws, domestic workers are exploited and face abusive behaviour of their employer. Which clearly indicates the violation of the constitution of Pakistan and it is because these laws are not implemented forcefully. Another reason of exploitation is lack of awareness of rights among domestic employees. Their ignorance becomes the reason of their victimization. Low status of women contributes in increasing their troubles and they cannot complain against the abusive behaviour of their employer, because they are powerful. Such worse working conditions lead to humiliation of domestic workers. Women's contribution in informal domestic employment sector is remarkable without any doubt, but unfortunately their efforts, hard work, triple burden and weak support system make them more vulnerable and their work remain unrecognized. This study has also analyzed the level of harassment and exploitation which directly affect women working in this specific field. The economic activities of this sector can be enhanced to its highest limits only by delegating these workers their rights lawfully, which include limited working hours, proper pay scale, and implementation of laws regarding domestic employment. As per findings of this study by interviewing hundred respondents it was evident that women's involvement in domestic employment is due to the fact that they do not have access to quality education and career opportunities. Since women are a major contributor in the informal sector and especially in domestic employment sector because it is considered that doing household chores is a woman's job, therefore, their domestic work should be properly recognized as work and any kind of discrimination should be eliminated. Maintaining their dignity as a woman and as a human is the need of the time.

\section{References}

Anti-Slavery International. "Domestic Work and Slavery". Anti-Slavery.Org. Anti-Slavery International. Retrieved on $24^{\text {th }}$ September, 2016.

Archer, S. (2011). Buying the Maid Recoffy: Domestic Workers, Employers and Food, South African Review of Sociology, vol. 40, pp.66-82.

Barrington, L. W. (2009). Comparative politics: Structures and Choices, Boston, MA, Cengage Learning.

Boonzaier, F. \& Shefer, T. (2006). Gendered research. In T. Shefer, F. Boonzaier \& P. Kiguwa (Eds.), The Gender of Psychology, Cape Town, South Africa: UCT Press, pp.3-11. 
Cock, J. (1980). Maids and Madams: A Study in the Politics of Exploitation, Johannesburg, S.A., Raven Press.

Cock, J. (1981). Disposable Nannies: Domestic Servants in the Political Economy of South of African, Political Economy, vol. 21, pp.63-83.

Cock, J. (1988). Maids and Madams: Domestic Workers Under Apartheid, London. The Women's Press.

Cock, J. (2011). Challenging the Invisibility of Domestic Workers, South African Review of Sociology, vol.42, pp.132-133.

Cohen, R. (1991). Women of Colour in White Households: Coping Strategies of Live-In Domestic Workers, Qualitative Sociology, vol.14, pp.179-215.

Cohen, R. (1991). Women of Colour in White Households: Coping Strategies of live-in Domestic Workers, Qualitative Sociology, vol.14, pp.179-215.

Cohen, R. (2000). Mom is A Stranger: The Negative Impact of Immigration Policies on the Family Life of Filipina Domestic Workers, Canadian Ethnic Studies, vol.32, pp.76-88.

David, M. Kennedy (1992). Culturgrams: The Nations Around Us: volume II: Africa, Asia and Oceania. Garrett Park, MD: Center for International Studies, Garrett Park Press, p.18.

De Regt, M. (2009). Preferences and Prejudices: Employers Views on Domestic Workers in the Republic Of Yemen, Journal of Women in Culture and Society, vol.34, pp.559-581.

DeVoe, D. (1990). Feminist and Non-sexist Counseling: Implications for the Male Counselor, Journal of Counseling \& Development, vol.61, pp.33-36.

Gaitskell, D., Kimble, J., Maconachie, M. \& Unterhalter, E. (1983). Class, Race and Gender: Domestic Workers in South Africa, Review of African Political Economy, vol.27, pp.86-108.

Government of Pakistan (2005). Labor Protection Policy 2005 (First Draft), Ministry of Labor, Manpower and Overseas Pakistanis, Available at http://www.tanqeed.org/2014/01/a-maids-work/ 
Griffin, L. (2011). Unravelling Rights: 'Illegal' Migrant Domestic Workers in South Africa, South African Review of Sociology, vol. 42, pp.83-101.

Guo, M., Chow, N.W.S. \& Palinkas, L.A. (2011). Circular Migration and the Life Course of Female Domestic Workers in Beijing, Asian Population Studies, vol.7, pp.51-67.

Hisham, Zeenat (2015). Hidden Worker: Published in Dawn, January 27th, 2015, Karachi, PILER.

ILO (1951). The Status and Conditions of Employment of Domestic Workers, Meeting of Experts, Geneva, Report 3, Document MDW/8.

Iqbal, Muhammad Javaid (2015). ILO Conventions and Gender Dimensions of Labour Laws in Pakistan, A Research Journal of South Asian Studies, vol.30:1, pp.257-271.

Little, William (1842). The illustrated London news, London: William Little, p.934.

Lycklama, G. (1989). Trade in Maids: Asian Domestic Helpers in Migration Theory and Practice, Kuala Lumpur, Asian Pacific.

M. Gallotti (2009). The Gender Dimension of Domestic Work in Western Europe, International Migration Papers, vol.96, pp.2-3.

Massey, D. S. \& K. Espinosa (1997). What's Driving Mexico-U.S. Migration? A Theoretical, Empirical, and Policy Analysis, American Journal of Sociology, vol.102:4, pp.939-999.

Mkandawire-Valhmu, L. (2010). Suffering in Thought: An Analysis of the Mental Health Needs of Female Domestic Workers Living in Malawi, Issues in Mental Health Nursing, vol.31, pp.112-118.

Mkandawire-Valhmu, L., Robriguez, R., Ammar, N. \& Nemoto, K. (2009). Surviving Life as a Woman: A Critical Ethnography of Violence in the Lives of Female Domestic Workers in Malawi, Health Care for Woman International, vol.30, pp.783-801.

Shahid, Ayesha (2007). Silent Voices, Untold Stories: Women Domestic Workers in Pakistan and their Struggle for Empowerment, UK, University of Warwick, available at http://www.tanqeed.org/?s=silent+voices+untold+stories 
Shahid, Ayesha (2014). A Maid's Work: Tanqeed Monthly Magazine, UK, University of Warwick, Available at http://www.tanqeed.org/2014/01/a-maids-work/

Shehzadi, Hina (2014). Insight into the Lives of Domestic Workers (Housemaids) in Pakistan, Available at http://www.copasah.net/uploads/1/2/6/4/12642634/ an_insight_into_the_lives_of_domestic_workers.pdf

StatsSA (Statistic South Africa). (2005). Labour Force Survey, September 2004. Pretoria: Statistic South Africa.

Ukwatta, S. (2010). Sri Lankan Female Domestic Workers Overseas: Mothering their Children from a Distance, Journal of Population Research, vol. 27, pp.107-131. 
Annex

Table: 1

Distribution of the respondents according to their age groups

\begin{tabular}{|l|c|c|}
\hline Age Groups in Years & Frequency & Percentage \\
\hline $11-15$ years & 14 & $14 \%$ \\
\hline $16-20$ years & 22 & $22 \%$ \\
\hline $21-25$ years & 21 & $21 \%$ \\
\hline $26-30$ years & 15 & $15 \%$ \\
\hline More than 30 years & 28 & $28 \%$ \\
\hline Total & $\mathbf{1 0 0}$ & $\mathbf{1 0 0 \%}$ \\
\hline
\end{tabular}

Table: 2

Distribution of the respondents according to their educational status

\begin{tabular}{|l|c|c|}
\hline Education & Frequency & Percentage \\
\hline Literate & 36 & $36 \%$ \\
\hline Illiterate & 64 & $64 \%$ \\
\hline Total & 100 & $100 \%$ \\
\hline
\end{tabular}

Table: 3

Distribution of the respondents according to their marital status

\begin{tabular}{|l|c|c|}
\hline Marital Status & Frequency & Percentage \\
\hline Unmarried & 33 & $33 \%$ \\
\hline Married & 29 & $23 \%$ \\
\hline Divorced & 14 & $14 \%$ \\
\hline Widowed & 12 & $12 \%$ \\
\hline Temporary Seperation & 12 & $12 \%$ \\
\hline Total & $\mathbf{1 0 0}$ & $\mathbf{1 0 0 \%}$ \\
\hline
\end{tabular}

Table: 4

Distribution of the respondents according to their monthly income

\begin{tabular}{|l|c|c|}
\hline Monthly Income of the Respondent & Frequency & Percentage \\
\hline $1000-3000$ & 36 & $36 \%$ \\
\hline $3001-5000$ & 20 & $20 \%$ \\
\hline $5001-7000$ & 18 & $18 \%$ \\
\hline $7001-9000$ & 16 & $16 \%$ \\
\hline More than 9,000 & 10 & $10 \%$ \\
\hline Total & $\mathbf{1 0 0}$ & $\mathbf{1 0 0 \%}$ \\
\hline
\end{tabular}


Table: 5

Distribution of the respondents according to reason of doing domestic work

\begin{tabular}{|l|c|c|}
\hline Reason of Doing Domestic Work & Frequency & Percentage \\
\hline Other Family Members Do Not Earn & 29 & $29 \%$ \\
\hline For Their Children & 23 & $23 \%$ \\
\hline To Improve Their Financial Status & 48 & $48 \%$ \\
\hline Total & $\mathbf{1 0 0}$ & $\mathbf{1 0 0 \%}$ \\
\hline
\end{tabular}

Table 6

Distribution of the respondents according to behaviour of owner with them

\begin{tabular}{|l|c|c|}
\hline Behaviour Of Owner With Them & Frequency & Percentage \\
\hline Good & 29 & $29 \%$ \\
\hline Bad & 19 & $19 \%$ \\
\hline Moody & 32 & $32 \%$ \\
\hline Caring & 20 & $20 \%$ \\
\hline Total & $\mathbf{1 0 0}$ & $\mathbf{1 0 0} \%$ \\
\hline
\end{tabular}

Table: 7

Distribution of the respondents according to awareness about sexual harassment

\begin{tabular}{|l|c|c|}
\hline Awareness About Sexual Harassment & Frequency & Percentage \\
\hline Yes & 66 & $66 \%$ \\
\hline No & 34 & $34 \%$ \\
\hline Total & $\mathbf{1 0 0}$ & $\mathbf{1 0 0 \%}$ \\
\hline
\end{tabular}

Table: 8

Distribution of the respondents according to have they ever been sexually harassed

\begin{tabular}{|l|c|c|}
\hline Have They Ever Been Sexually Harassed & Frequency & Percentage \\
\hline Yes & 54 & $54 \%$ \\
\hline No & 46 & $46 \%$ \\
\hline Total & $\mathbf{1 0 0}$ & $\mathbf{1 0 0 \%}$ \\
\hline
\end{tabular}

Table: 9

Distributions of the respondents according to what extent of sexual harassment occurred

\begin{tabular}{|l|c|c|}
\hline What Extent of Sexual Harassment Occurred & Frequency & Percentage \\
\hline To The Extremes & 15 & $15 \%$ \\
\hline Touching And Holding Hands & 33 & $33 \%$ \\
\hline Making Love & 16 & $16 \%$ \\
\hline Not Harassed & 36 & $36 \%$ \\
\hline Total & $\mathbf{1 0 0}$ & $\mathbf{1 0 0} \%$ \\
\hline
\end{tabular}


Table: 10

Distribution of the respondents according to their reaction after sexual harassment

\begin{tabular}{|l|c|c|}
\hline Their Reaction After Sexual Harassment & Frequency & Percentage \\
\hline Said Abusive Words & 16 & $16 \%$ \\
\hline Got Angry & 26 & $26 \%$ \\
\hline Rude Attitude & 22 & $20 \%$ \\
\hline Not Harassed & 36 & $36 \%$ \\
\hline Total & $\mathbf{1 0 0}$ & $\mathbf{1 0 0 \%}$ \\
\hline
\end{tabular}

Table: 11

Distribution of the respondents according to did they inform any one about their sexual harassment

\begin{tabular}{|l|c|c|}
\hline $\begin{array}{l}\text { Did They Inform Their Owner About Their } \\
\text { Sexual Harassment }\end{array}$ & Frequency & Percentage \\
\hline Yes & 31 & $31 \%$ \\
\hline No & 29 & $29 \%$ \\
\hline Not Harassed & 40 & $40 \%$ \\
\hline Total & $\mathbf{1 0 0}$ & $\mathbf{1 0 0 \%}$ \\
\hline
\end{tabular}

Table: 12

Distribution of the respondents according to did they warn their female relatives about sexual harassment after being victimized

\begin{tabular}{|l|c|c|}
\hline $\begin{array}{l}\text { Did They Warn Their Female Relatives About } \\
\text { Sexual Harassment After Being Victimized }\end{array}$ & Frequency & Percentage \\
\hline Yes & 24 & $24 \%$ \\
\hline No & 36 & $36 \%$ \\
\hline Not harassed & 40 & $40 \%$ \\
\hline Total & $\mathbf{1 0 0}$ & $\mathbf{1 0 0 \%}$ \\
\hline
\end{tabular}

Table: 13

Distribution of the respondents according to did anyone share their sexual harassment incident with you

\begin{tabular}{|l|c|c|}
\hline $\begin{array}{l}\text { Did Anyone Share Their Sexual Harassment } \\
\text { Incident With Them }\end{array}$ & Frequency & Percentage \\
\hline Yes & 50 & $50 \%$ \\
\hline No & 50 & $50 \%$ \\
\hline Total & $\mathbf{1 0 0}$ & $\mathbf{1 0 0 \%}$ \\
\hline
\end{tabular}


Table: 14

Distribution of the respondents according to did they give any advice to sexual harassment victim

\begin{tabular}{|l|c|c|}
\hline $\begin{array}{l}\text { Did They Give Any Advice To Sexual } \\
\text { Harassment Victim }\end{array}$ & Frequency & Percentage \\
\hline Yes & 37 & $37 \%$ \\
\hline No & 63 & $63 \%$ \\
\hline Total & $\mathbf{1 0 0}$ & $\mathbf{1 0 0 \%}$ \\
\hline
\end{tabular}

Table: 15

Distribution of the respondents according to do you face mental stress and depression due to sexual harassment

\begin{tabular}{|l|c|c|}
\hline $\begin{array}{l}\text { Do They Face Mental Stress And Depression Due } \\
\text { To Sexual Harassment }\end{array}$ & Frequency & Percentage \\
\hline Yes & 30 & $30 \%$ \\
\hline No & 30 & $30 \%$ \\
\hline Not Harassed & 40 & $40 \%$ \\
\hline Total & $\mathbf{1 0 0}$ & $\mathbf{1 0 0} \%$ \\
\hline
\end{tabular}

Table: 16

Distribution of the respondents according to do you know about sexual harassment bill

\begin{tabular}{|l|c|c|}
\hline Do They Know About Sexual Harassment Bill & Frequency & Percentage \\
\hline Yes & 14 & $14 \%$ \\
\hline No & 46 & $46 \%$ \\
\hline Not harassed & 40 & $40 \%$ \\
\hline Total & $\mathbf{1 0 0}$ & $\mathbf{1 0 0 \%}$ \\
\hline
\end{tabular}

Table: 17

Distribution of the respondents according to your opinion about sexual harassment

\begin{tabular}{|l|c|c|}
\hline Their Opinion About Sexual Harassment & Frequency & Percentage \\
\hline Men Always Exploit Women & 31 & $31 \%$ \\
\hline $\begin{array}{l}\text { Women Are Physically Weak And Become } \\
\text { Harassment Victim Easily }\end{array}$ & 26 & $26 \%$ \\
\hline Men Manipulate Women And Exploit Them & 19 & $19 \%$ \\
\hline $\begin{array}{l}\text { Women Should Be Strong So That Men Cannot } \\
\text { Harass Them }\end{array}$ & 24 & $24 \%$ \\
\hline Total & $\mathbf{1 0 0}$ & $\mathbf{1 0 0 \%}$ \\
\hline
\end{tabular}


Seema Manzoor is Lecturer in the Centre of Excellence for Women's Studies, University of Karachi.

Dua-e-Rehma is Lecturer in the Centre of Excellence for Women's Studies, University of Karachi.

Dr. Misbah B. Qureshi Professor \& Director in the Institute of Gender Studies, Sindh University Jamshoro.

Dr. Muhammad Shahid is an Associate Professor in the Department of Social Work, University of Karachi. 